\title{
Beyaz Tekstil ve Giyim Ürünlerinde Anlam
}

\author{
Meaning in White Textile and Garment Products \\ Cemal Meydan, Tekstil ve Moda Tasarımı, Dokuz Eylül Üniversitesi \\ Gözde Ağca, Tekstil ve Moda Tasarımı, Dokuz Eylül Üniversitesi
}

\begin{abstract}
Özet
Bir tekstil ya da giysinin sosyal düzeyde anlamlandırılmasında renk önemli bir unsuru oluşturmaktadır. Tekstiller ya da giysiler renkleri ile ait olduğu kültür, coğrafya, inanç sistemi ile çeşitli sembolik roller üstlenebilmektedir. Bu doğrultuda geçmişten günümüze geniş bir anlam çeşitliliğine sahip olan beyazın, kendi anlamını bağlı olduğu tekstil ya da giysi örneklerine yansıtarak, güçlü çağrışımlar kazandırdığı mevcut örnekleri üzerinden açıç̧a gözlemlenebilmektedir.
\end{abstract}

Beyaz genel olarak, aydınlık, saflık, kutsallık, günahsızlık, bekaret, eşitlik, temizlik, güç, umut çağrışımları ile öne çıkmaktadır. Bu çağrışımları ile bağlantılı olarak beyaz, kutsal kabul edilen kişilerin giysileri ve aksesuarlarında tercih edilen bir renk olmuștur. Beyaz aynı zamanda kültürel olarak yüceltilen, adalet ve eşitliği savunan, yüksek makam ya da mevki sahibi kişiler ile özdeşleştirilmiş ve kullanımı sınırlandırılmıștır. Beyaz, mendil ve bayrak gibi örnekleriyle sözsüz bir iletişim aracı rolü üstlenmiş, belirli bir ideoloji ya da amaca yönelik gelişen gruplar ve uygulamalar ile hem görsel hem iletişimsel bir işlev kazanmıştır.

$\mathrm{Bu}$ çalışmada beyazın anlam ve çağrıșımlarının, tekstil ve giysi ürünlerinin mevcut anlamlarını nasıl etkilediği ve şekillendirdiği araştırılmıștır. Bu doğrultuda, yazılı ve görsel kaynaklar taranarak, zaman ve mekân gözetilmeksizin beyaz tekstil ve giysi örnekleri bir araya getirilmiş ve anlamsal kazanımları göz önünde tutularak belirli kategoriler altında toplanmıștır. Beyazın tarihsel yolculuğu belirli örnekler üzerinden ortaya konulmaya çalışılmıştır.

Anahtar Sözcükler: Beyaz tekstiller, beyaz giysiler, din ve tören, ritüel ve iletişim, ideoloji ve statü, protesto ve farkındalık.

Akademik disipin(ler)/alan(lar): Tekstil tasarımı, moda tasarımı, sosyolojide renk algisı.
Abstract

Color is an important element in making sense of a textile or garment on a social level. Textiles or garments can hold various symbolic roles by making sense of the culture, geography, belief system to which it belongs with its colors. In this respect, it can be clearly observed through existing examples that white, which has a wide variety of meanings from past to present, reflects its own meaning to textile or clothing samples and accretes strong connotations.

White generally stands out with its connotations of lightness, pureness, holiness, sinlessness, chastity, equality, cleanliness, power, hope. Along with these connotations, white has become a preferred color in the clothes and accessories of holy persons or clergy. White has also been identified with and restricted in use by those who are culturally exalted, advocating justice and equality, holding high office or position. White has taken the role of a non-verbal communication tool in conjunction with examples such as handkerchiefs and flags, has gained both a visual and communicative function with groups and practices developed for a particular ideology or purpose.

In this study, it was researched how the meanings and associations of white affect and shape the current meanings of textile and clothing products. For this purpose, by scanning written and visual resources, white textile and clothing samples were brought together regardless of time and place, and were grouped under certain categories considering their semantic achievements. White's historical journey has been revealed through specific examples.

Keywords: White textiles, white garments, religion and ceremony, ritual and communication, ideology and social status, protest and awareness.

Academical disciplines/fields: Textile and fashion design, color perception in sociology.

- $\quad$ Sorumlu Yazar: Cemal Meydan, Tekstil ve Moda Tasarımı Bölümü, Güzel Sanatlar Fakültesi, Dokuz Eylül Üniversitesi.

- $\quad$ Adres: Dokuz Eylül Üniversitesi, Tınaztepe Yerleşkesi, Adatepe Mah. Doğuş Cad. No:209, 35390, Buca, İzmir.

- $\quad$ e-posta: cemal.meydan@deu.edu.tr

- ORCID: 0000-0002-6185-0151

- Cevrimiçi yayın tarihi: 22.09 .2021

- doi: $10.17484 /$ yedi.893085 


\section{Giriş}

Renklerin bir kişinin kimliğini yansıtabildiği ya da bir iletişim aracı olarak kullanılabildiği düşünülmektedir (Nazri vd., 2015, s. 3). Bu doğrultuda, tekstil ürünlerine renkleri ile bağlantılı olarak iletişimsel işlevler ve kavramlar atfedilebilmektedir. Her ne kadar bir ürün ile birlikte yorumlandığ düşünülse de rengin anlamı büyük ölçüde rengin kendi tarihi ile ilişkilidir. Rengin anlamını ise zaman içindeki hareketi oluşturmaktadır (Harvey, 2008, s. 80).

Beyaz, insanlık tarihinde uzun bir geçmişe sahip olmuş, bu süreçte gerek bir renk olarak gerek birleştirildiği ürün ile yorumlanarak sosyal düzeyde birçok anlam atfedilmiş ve dolaylı olarak bir iletişim aracına dönüşmüştür. Tekstil ve giysi örnekleri üzerinden ele alındığında çoğunlukla beyazın kendi etimolojik ve sembolik anlamlarını bu ürünlere taşıdığını ve bu ürünlere kendi rollerinden daha baskın ifadeler kazandığı söylenebilmektedir. Bu doğrultuda öncelikli olarak beyazın kendi anlamı, etimolojisi ve sembolizminin araştırılması, beyaz tekstil ve giysi ürünlerinin iletişimsel rolleri ile ilişkilendirilerek çeșitli tespitler yapılabilmesine olanak sağlamaktadır.

“Türkçe beyaz kelimesinin etimolojik kökeni Arapça'dır. Arapça'da “byḍ kökünden gelen bayāḍ بياض beyaz olma, beyazlık, beyaz renk kelimesinden geçmiştir" (Etimolojitürkçe, t.y.). Merriam-Webster sözlüğüne göre beyaz kelimesinin İngilizce kökeni white eski İngilizce hwït kelimesinden evrilmiştir; eski yüksek Almanca hwīz (beyaz), Slav světŭ (1şık), Sanskrit śveta (beyaz veya parlak) kelimeleri ile benzerlik göstermektedir (Blumhagen, 1979, s. 114).

Beyaz, ıșığın mutlak rengi olarak tanımlanabilmektedir (Yu, 2014, s. 64). Tarihte renk teorileri incelendiğinde, teorilerde beyazın ve beyaz ışığın diğer renklerin oluşumundaki etkisi üzerine yorumlarla karşılaşılmaktadır. Bilinen ilk renk teorisini geliştiren Aristoteles'e göre tüm renkler beyaz ve siyahtan (aydınlık ve karanlıktan) gelmiş ve dört elementle (su, hava, toprak ve ateş) ilişkili olmuştur. Bu görüş Newton'un teorisine kadar yaygın bir biçimde benimsenmiştir. Isaac Newton berrak beyaz ișı̆̆ın yedi görünür renkten oluştuğunu göstermiștir. Görünür spektrum, elektromanyetik spektrum içindeki insan gözüyle görülebilen dar kısımdır (Smithsonian Libraries, t.y.). Fizik alanı kapsamında beyaz, görünür spektrumun tüm dalga boyları birleştiğinde insan gözü tarafından görülen ışık olarak ifade edilmektedir. Renk tayfının renklerinden ve bu renklerin karışımlarından farklı olarak beyazın ve benzer biçimde siyahın tonu yoktur, bu nedenle beyaz akromatik bir renk olarak kabul edilmektedir (Britannica, t.y.).

Işık ile ilişkilendirilmesi beyaza diğer renklere görece daha güçlü bir etki alanı yarattığı düşünülebilmektedir. Bu doğrultuda beyazın insanların inanç ve duygu dünyalarında somut ve soyut çağrışımlara aracılık ettiği, olumlu ya da olumsuz anlamlar atfedilebildiği görülebilmektedir. Olumlu açıdan incelendiğinde; beyaz genel bir ifade ile gerçeği, saflığı, masumiyeti, bekareti ve kutsal ya da ilahi olanı sembolize etmektedir (Yu, 2014, s. 54-64). Beyaz renk, Müslümanlık, Hristiyanlık, Yahudilik gibi geniş kitleye sahip dinlerde kutsal bir renk olarak yorumlanmaktadır. Bu kapsamda beyaz, gerçek ve mecazi boyutta dini kitaplarda bahsedilen, dini tasvirlerde kullanılan ve ritüel giysilerinde tercih edilen bir renk olmuştur.

Psikolojik olarak beyazın temel özelliği; eşitliği, adaleti, tarafsızlı̆̆ı ve bağımsızlığı ifade etmesidir. Beyaz aynı zamanda ilerleyen örneklerde bahsedileceği gibi psikolojik olarak duygusal nötrlük, güven, güç ve sorumluluk gibi ifadelerin yansıtılmasında ve anımsatılmasında aracı olabilmektedir. Beyaz yansıtıcı bir renktir; açıklığı, büyümeyi ve yaratıcılığı destekleyerek; huzur, sakinlik, rahatlık ve umut duygusu vermektedir (Nazri vd., 2015, s. 2-13).

İnsan ile iletişiminin bir sonucu olarak beyaz kültürel bağlamda da çeşitli sembolik anlamlar ve çağrışımlar kazanmıștır. Türk kültüründe beyaz renk, beyazlığı, temizliği, arılığı, büyüklüğü, olgunluğu ve adaleti temsil etmiştir. Beyaz, Türkler için ayrıca batı istikametini sembolize eden bir renk olmuştur (Soysal, 2010, s. 218-220). Batı kültürüne kıyasla Doğu kültürlerinde beyaz olumsuz çağrışımları ile öne çlkmaktadır. Çin, Japon ve birçok Afrika milletine göre beyaz renk ölümün rengini temsil etmektedir (Edwards, 2004, s. 174). Ölüm sonrasında matemin bir ifadesi olarak Hindistan, Çin ve bazı tropik ülkeler, kültürleri ile bağlantılı olarak beyaz giysiler tercih edilmektedir (Nazri vd., 2015, s. 8). Çin'de beyazın kötülük ile ilişkilendirilebildiği de görülmektedir. Çin sahnelerinde oyuncuların yüzlerini beyaza boyamaları o kişinin kurnaz ve hain olduğuna işaret etmektedir. Çin'de beyaz aynı zamanda sonbaharın rengi ve yaşlılığın bir çeşit amblemi olarak kabul edilmektedir (Yu, 2014, s. 45-65).

Giysiler ve tekstil ürünleri renkler ile de iletişim kurabilmektedir (Meydan ve Yıldız, 2018, s. 906). Tüm bu çağrışımları ile beyaz renk tekstil ve giysi örnekleri üzerinde de etkin olmuş ve ürünü iletişimsel boyutta 
şekillendirmiştir. Bu doğrultuda beyaz tekstiller ve giysiler bir amaç ya da inanç doğrultusunda kullanılarak, belirli bir anlamın oluşturulması ya da bir anlama yönlendirilmesinde bir aracı rolü üstlenebilmiștir. Saptanan mevcut örnekler doğrultusunda inanç kapsamında beyaz renkli ürünler; kutsal olanı, ideali, yüksek mertebeyi ve saflı̆ı işaret etmektedir. Ritüellerde kutsama, ata ile iletişim kurma, manevi arınma, ölüye veda etme, yas tutma ve evlilik gibi amaçlara aracılık etmektedir. Sosyolojik boyutta ise statü ve ideoloji işaretçisi olabilirken belirli durumlarda protesto aracı olarak da kullanılabilmektedir. Beyazın fiziki anlamdaki çağrışımı hijyen gerektiren meslek gruplarının üniformalarını şekillendirebilirken, parlak görüntüsü fonksiyonel boyutta da giysi tercihlerini etkileyebilmektedir. Anma törenlerinde görsel bir araç olarak sembolik roller üstlenebilmektedir.

Bu çalışmada beyazın; din, tören, kültür, ritüel, statü, ideoloji, temizlik, protesto, iletişim ve farkındalık çağrışımları kapsamında, giyim ve tekstil ürünleri ile ilişkisinin saptanması amaçlanmıştır. Yapılan araştırma sonucu bir araya getirilen geçmiş ve güncel ürünler retrospektif bir bakış açısı ile incelenmiş, beyaz rengin bu ürünler ile anlam hareketliliği gözlenerek sosyal düzeyde değerlendirilmiștir.

\section{Beyaz Tekstil ve Giysilerde Anlam Grupları}

\subsection{Din ve Tören}

Beyaz renk gerek küçük grupların inançlarında gerek Musevilik, Hristiyanlık, Müslümanlık gibi geniş̧ kitlelere hitap eden dinlerde çeşitli biçimlerde yer edinmiştir. Büyük dinleri ve bu dinlerin iki bin yılı aşan geçmişi ele alındığında beyaz rengin ve beraberinde beyaz giysi ve tekstil örneklerinde, belirli anlamlarda benzer ya da farklı biçimde roller üstlendiği görülmektedir. Genel olarak beyaz giysiler Eski Ahit'ten Kur'an'a dini kitaplarda ve hadislerde bahsi geçen, dini tasvirlerde yer alan, dini vazifeye sahip kişilerce giyilen, dini ve vazifelerde uygun görülen ürünler olmuştur.

Musevilikte beyazın tekstil ve giysi ürünlerinde dini amaçlar doğrultusunda tercih edilen bir renk olduğu görülmektedir. Musa'nın Sanhedrin isimli, Yahudiler'in yönetimine destek veren bir kurulu olduğundan bahsedilmektedir. Bu kurulda yer alma potansiyeline sahip rahipler, saflıkları ve arka planları ile değerlendirildiği ve başarılı olan rahiplerin beyaz giydiği bilinmektedir (Gordon, 2011, s. 254).

Gelenekler doğrultusunda Museviler, Yom Kippur, Fısıh Bayramı ve Şabat gibi kutsal günlerde beyaz renkli giysiler tercih edebilmektedir. Yom Kippur, Musevi yeni yıl olan Rosh Hashanah sonrasında, geçmiş yılda işledikleri günahları için af diledikleri bir çeşit tövbe gündür. Saflı̆̆ın sembolü olarak beyaz giyinmek Yom Kippur'un bir işaretçisi olarak yorumlanabilmektedir. Bu tövbe gününde geleneksel olarak beyaz renkli giysiler ya da kittel isimli beyaz bir giysi tercih edilebilmektedir (Whitfield, 2018). Beyaz ve saflık ilişkisi ise Hz. Zülkifl ve Hz. Danyal'ın melekleri beyaz ketenler içerisinde tarif etmesi ile ilişkili olduğu düşünülebilmektedir (Shurpin, t.y.). Fısıh Bayramı ya da Hamursuz Bayramı'nda da beyaz giyinmek az da olsa bilinen bir gelenektir. Aşkenazi Yahudileri'nde sadece hane reisi beyaz renkli giysiler giymektedir. Musevilerin Şabat'ta beyaz giyinmesi her ne kadar evrensel olarak kabul görmemiş görünse de geçmişte Sefarad ve Şasidik toplulukları arasında popüler olmuş ve az bilinen bir gelenek olarak varlığını sürdürebilmiștir. Beyaz giyme geleneği kabala kökenlidir. Kişinin Şabat'ta giydiği rengin gelecek dünyada giydiği renk olacağını öğreten Haham Isaac Luria'nın öğretisi ile ilişkilendirilebilmektedir (Wearing White for Shabbat, 2016).

Hristiyanlıkta beyaz renk; baba oğul ve kutsal ruhun, Hz. İsa'nın, saflığın ve sevincin rengi olarak tanınmaktadır. Bu renk, Noel zamanında, Epifani Bayramı́nda, Paskalya zamanında, Yükseliş Günü’nde, Başkalaşım Bayramı'nda, Azizler Günü'nde ve Oktavında, Şükran Günü'nde, Bağımsızlık Günü'nde, evliliklerde ve belirli bazı bayramlarda kullanılmaktadır (Allsaintanglican, t.y.).

Hristiyan din adamlarının giysilerinde beyaz renkli örnekler mevcuttur. Katolik rahip cübbelerinin altına giydikleri, geleneksel olarak beyaz renkli ve keten kaftanlar örnek olarak gösterilebilmektedir. $\mathrm{Bu}$ giysilerin geçmişi Roma İmparatorluğu'nda Hristiyanlığın başlangıcına kadar uzanmaktadır. Bu kaftanlar İngilizcede 'alb' olarak adlandırılmaktadır. 'Alb' kelimesi ise Latincede beyaz anlamına gelen alba'dan gelmektedir (Kosloski, 2017). Albler papazların ruhunu süsleyen masumiyet ve saflı̆ı sembolize etmektedir (Knowing the Differences Between Albs and Surplices, 2018). Genel olarak Papa'nın cübbeleri de beyazdır ve İsa'nın ihtişamına en yakın irtibata sahip olduğunu göstermektedir (Catholic Liturgical Colors, 2018). Hristiyan sanatının bir parçası olan diriliş tablolarında İsa çoğunlukla beyaz giysiler içerisinde tasvir edilmektedir (Jameson, 1848, s. 45). Genel olarak Hristiyan melekler ve klyamet günü resimlerinde adil ruhlar da beyaz giysiler içerisinde tasvir edilmektedir (Yu, 2014, s. 64-65). 
Geçmiş yüzyıllarda kiliselerde giysisiz olarak vaftiz edilenlere ilk olarak, Hristiyanlıkta yeni doğuşu sembolize eden beyaz giysiler verilmiştir. $\mathrm{Bu}$ yeni başlangıca eșlik eden beyaz elbisenin hayat boyu günahlar ile manevi olarak kirletilmemesi, ölüm sonrasında cennete hazır olunması durumuna işaret edeceğine inanılmaktadır (Kosloski, 2017) Katolik aileler, çocuklarının katılım gösterdikleri ilk Efkaristiya ayininde erkek çocuk için takım elbise, kız çocuk için beyaz elbise ve duvak tercih edebilmektedir (Stith, 2015, s. 93). Erken dönem Hristiyan teologları, bakire kişilerin duvak takmalarını manevi boyutta 'İsa'nın Gelini' olma durumu ile ilişkilendirmektedir (Castelli, 1986, s. 71). Geleneğin bir parçası olarak erkekler de sol kollarına beyaz kurdele bağlayabilmektedir (Jarvis, 2007, s. 86) (Şekil 1). Bazı ayinlerde hem kız hem erkek aynı tipte beyaz cübbeler giyebilmektedir. Kızların tercih ettiği beyaz elbiseler saflığı, iffeti ve Tanrı'ya itaati sembolize etmektedir (Stith, 2015, s. 94).

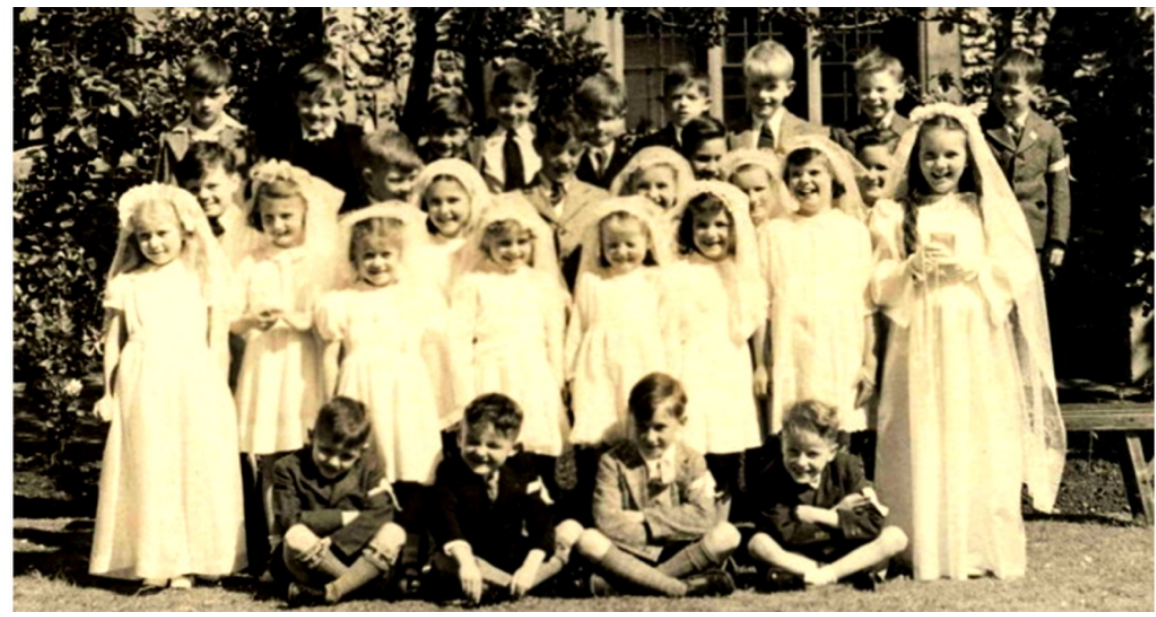

Şekil 1. Bir grup çocuğun ilk Efkarsitiya ayini portresi, Holyrood School, Swindon, 1949, (Wikimedia, 2007).

Hristiyanlığa ait yazılı kaynaklarda beyaz renk çoğu zaman lekesiz, ya da lekeden temizlenmiş olma hali olarak ifade edilebilmektedir. Bu tasvirler çoğunlukla günahsız olma, günahtan arınma ya da adanmışlık olarak yorumlanmaktadır. Bu duruma bir örnek olarak Aziz Yuhanna'nın Yedi Kiliseler'e mektuplarından Sardis mektubu örnek gösterilebilmektedir. Aziz Yuhanna'nın İ.S. 94-95 yıllarında Patmos Adası'nda yazdığı düşünülen bu mektubunda, aşağıdaki cümleleri yer almaktadır:

(...)Fakat Sardis'te birkaç kimselerin var ki onlar kendi esvaplarını kirletmediler ve benimle beraber beyazlarda yürüyecekler çünkü layıktırlar. Galip olan böylece beyaz esvapla giyinecek ve onun adını hayat kitabından silmeyeceğim ve onun adını Babamın indinde ve onun meleklerinin indinde ikrar edeceğim... (Yuhanna Vahiy, 3:1- 6). (Kunt ve Güngör, 2017, s. 73-79)

Bu doğrultuda beyaz giysiler kișinin inancının ve günahsızlığının bir işaretçisi olarak anlaşılabilmektedir.

Hristiyanlık inancında beyazın sembolizmi, Müslümanlık ile benzerlik göstermektedir. İslam'da beyaz, ışığın yani nurun ve parlaklığın simgesidir (Tez, 2009, s. 309). Cennet anlatılarında da beyaz renkli tasvirler ile karşılaşılmaktadır. Hz Muhammed'in rüyasında süt kadar beyaz nehirlerin olduğu ve kendisini bembeyaz bir köşkün beklediği bir cenneti gördüğünden bahsedilmektedir (El-Buhârî, 2009). Farklı bir örnekte ise Hz. Muhammed'in Hacer-ül Esved'in sütten beyaz olduğu fakat Adem'in çocuklarının günahları ile karardığını söylediği rivayet edilmektedir (Sunnah, t.y. a).

Hz. Muhammed'in beyaz rengi saflığın ve temizliğin işareti olarak seçtiğine inanılmaktadır. Beyaz giysilerin ve kumaşların kiri ve lekeleri belirgin bir şekilde göstermesi temizlik ile ilişkilendirilmesi altında yatan sebep olarak görülebilmektedir. Sahabelerinin gözlemlerine göre de Hz. Muhammed çoğunlukla beyaz renkli giysiler giymiştir (Nazri vd., 2015, s. 3-7). Beyaz giysiler içerisinde bahsedildiği bir hadis de mevcuttur. Ebû Zerr'in aktarımına göre "Ben bir keresinde Peygamber (S)'e ziyarete geldim; 0, üzerinde beyaz bir elbise olduğu halde uyuyordu...” (El-Buhârî, 2009). Meleklerin dünyada beyaz giysiler içerisinde görüldüğüne dair de hadislere rastlanmaktadır. Sahîh-i Buhârî, de bahsedilene göre Uhud Muhaberesi'nde, Hz. Muhammed'in yanında beyaz giysiler içerisinde Cebrail ve Mikail melekleri yer almıştır (Nazri vd., 2015, s. 7).

Hz. Muhammed'in bir duasında beyaz kumaşların kirden temizlenmesi ile affedilme ilişkisi kurduğundan bahsedilmektedir. Sahîh-i Buhârî̀de yer alan Ebu Hureyre'nin aktarımına göre Hz. Muhammed duasında 
"Ya Allah, benimle, günahlarım arasını, doğu ile batı arasını uzaklaştırdığın gibi uzaklaştır. Ya Allah, beyaz kumaş kirden temizlendiği gibi, beni günahlarımdan temizle. Ya Allah - geçmiş- günahlarımı da su ile kar ile dolu ile tertemiz yıka derim" sözlerini sarfetmiştir (El-Buhârî, 2009).

Hz. Muhammed'in hadislerinde beyaz, Müslümanlar için hem yaşamda hem de ölümde tavsiye edilen ve uygun görülen bir renk olarak yorumlanabilmektedir. "Beyaz elbise giyiniz. Şüphesiz bu, elbiselerinizin en hayırlısıdır. Ölülerinizi de onunla kefenleyiniz" (Sorularla İslamiyet, t.y.). Hz. Muhammed'in de beyaz ile kefenlendiğinden bahsedilmektedir “... Âișe (R) șöyle demiștir: Rasûlullah (S) pamuktan, suhûliyye denilen üç parça beyaz Yemen bezi içinde kefenlendi. Bu kefen parçalarının içinde gömlek ve başlık yoktu” (ElBuhârî, 2009).

Beyaz, Müslüman cenazelerinde ölen kișinin kefen rengidir. Kefen hem kadın hem de erkek için kullanılan ve bedeni örtmeye yarayan bir kumaştır. İslam inancında kefen farz-ı kifaye'dir. Yani bu farz yerine getirilmez ise İslam toplumu bu sorumluluğu üstlenmektedir (Sorularla İslamiyet, t.y.). Beyaz, merhumun saflık mertebesine geçişini işaret etmektedir. Ölen kişinin ardından; hatalarından, beyaz bir kumaşın kirlerinden arındığı gibi arınması için dua edilmektedir (Gordon, 2011, s. 257). Ölülerin beyazlar içerisinde gömülmesi İslam inanışından farklı dinlerde de neredeyse ortak bir renk haline gelmiştir. Beyaz, ölüye duyulan saygının da bir çeşit ifadesi olarak yorumlanmaktadır (Nazri vd., 2015, s. 4).

Hac ibadetini yerine getirmek amacı ile Mekke'ye giden Müslümanlar, şehir sınırından itibaren ihram adı verilen beyaz giysiler giymektedir (Gordon, 2011, s. 256-257) (Şekil 2). İhram içerisinde, yani bu beyaz ve lekesiz örtüler içerisinde kişinin gösteriş ve kibirden sakınması beklenmektedir. İhram Hac için toplanan tüm Müslümanlara bir çeşit eşitlik duygusu da yaratmaktadır (Öğüt, t.y.).

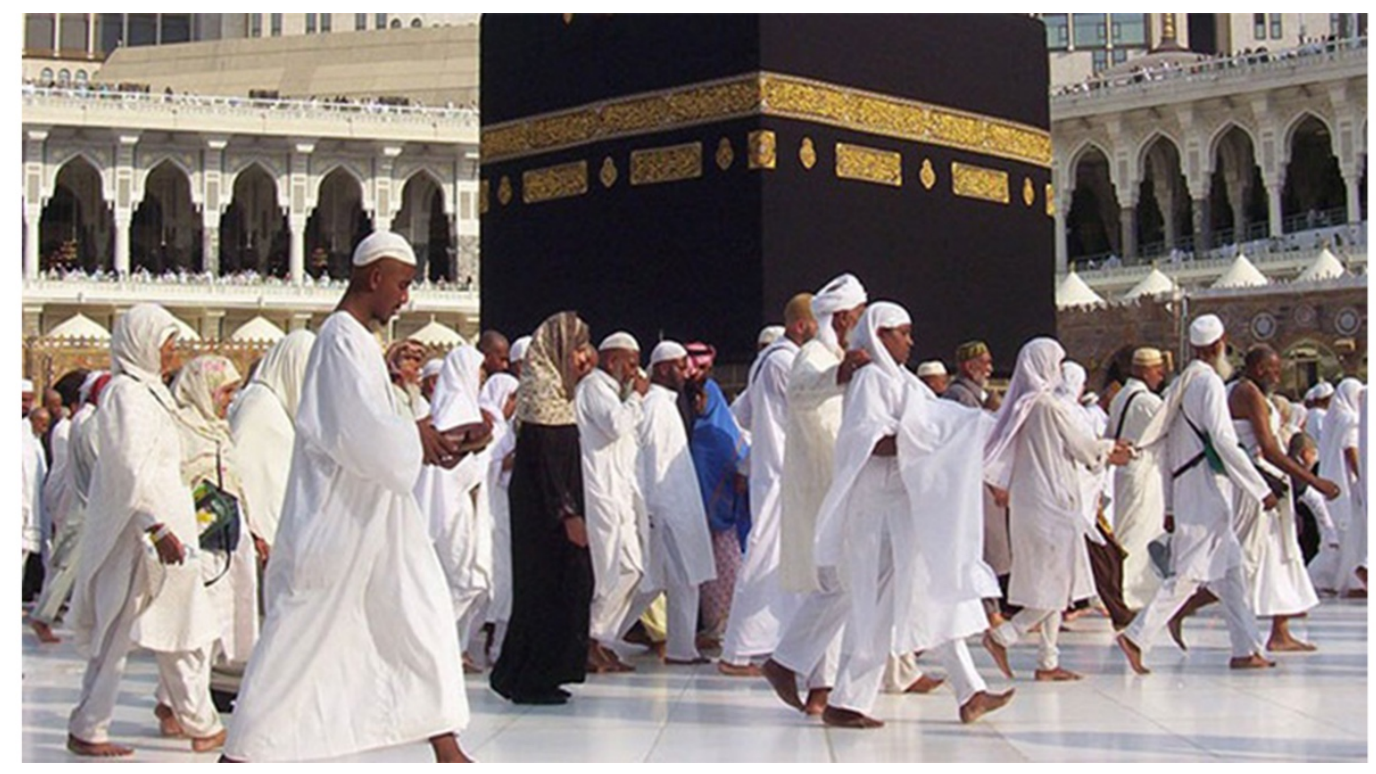

Şekil 2. İhram içerisinde Hac ibadetini gerçekleştiren Müslümanlar (Manevi destek dayanışma, 2019).

\subsection{Ritüel ve İletişim}

Dini ritüellerin yanı sıra kültürler de çeşitli ritüellerin gelişmesinde önemli bir rol oynamaktadır. Ölüm, doğum, evlilik dünya üzerinde örnek gösterilebilecek yaygın örnekler arasındadır. Bu ritüeller gerek inanç gerek kültür ile şekillenerek çeşitli gelenekler aracılığı ile süregelen uygulamalardır.

Ölüm ritüelinin bir parçası olarak yas sürecinde de çeşitli geleneksel uygulamalara yer verilmektedir. Beyaz, özellikle Çin, Afrika'nın bazı kesimleri, Hindistan ve birçok tropik ülkede geleneksel olarak ölüm ve yas ile ilişkilendirilmektedir. Genel olarak ölüm bir başlangıç olarak görülmektedir. Saflık ile iliş̧ilendirilen beyazın ise ölen kişinin yeni hayatına geçişine eşlik ettiğine inanılmaktadır. (Nazri,vd., 2015, s. 8). Reenkarnasyona inanan Budistler ölünün yeniden doğuşunu teşvik etmek adına beyaz giysiler giyebilmektedir. Konfüçyüsçü geleneğe göre de beyaz giysiler yası ifade etmektedir (Isaacs, 2020, s.10). Çinliler için beyaz, anne sütünü ve dolayısıyla umudu sembolize etmektedir (Pomfret, 2006, s. 191). Çinlilerin cenazelerde beyaz renk giysileri tercih etmeleri bu inanış ile ilișkilendirilebilmektedir.

Beyaz, Hint kültüründe ölümü sembolize etmektedir. Eşin ölümü ile dul olarak nitelendirilen kadınların yas göstergesi olarak, bir yıl boyunca beyaz giysiler ya da beyaz sariler giymeleri, makyaj yapmamaları ve 
mücevher kullanmamaları beklenmektedir. Bu beklenti zorunluluktan çok Hint geleneğinin toplumsal bir yansımasıdır (Gupta, 2011, s. 256-258). Hintli bir kadının eşini kaybetmesi ile birlikte hayat ile yüzleşeceği ve mücadele etmesi gerekeceği düşünülmektedir. Beyaz giysilerin, yas ifadesine ek olarak kişi üzerinde pozitif bir etki yarattığına ve kadına zorlu mücadelesinde destek olabileceğine inanılmaktadır (Desk, 2011). Gupta ayrıca 2010'da güncel durumun değişim gösterdiğinden bahsetmektedir. Eşini kaybeden kadınlar mevcut yaşam şartları doğrultusunda birkaç gün beyaz ve takiben birkaç sene açık renkli giysiler tercih edebilmektedir. Beyaz renkli giysiler bu doğrultuda yeni evli çiftler için uygun bir hediye olarak görülmemektedir (Gupta, 2011, s. 256-258).

Slavlar'da da yas beyaz giysiler ile ifade bulmuștur. Ölen kişinin yakınları düz beyaz bir gömlek ya da sarafan giyerek ve beyaz bir baş örtüsü takarak yaslarını ifade etmişlerdir. Tatar Türkleri'nde, Kırgız ve Kazaklar'dan farklı olarak beyaz giysiler ile yas tutulmaktadır. Kazak geleneğinde ise bir kız, babasını kaybettiğinde beyaz elbise ve kırmızı şapkası ile yas tutmaktadır ayrıca ölen kişinin çadırı da beyazdır (Özcan, 2008, s. 275-276).

Orta Çağ'da, Avrupa kraliçelerinin yaşanan ölümler sonrasında beyaz giysiler ile yas tuttukları örneklerine rastlanmıştır (Isaacs, 2020, s. 10). Dönemin tabloları ve tasvirlerinde dul eşler beyazlar içerisinde gösterilmektedir. Fransızca 'Deuil blanc' yani beyaz yas söylemi, 16. yüzyılda öksüz çocukların ve bekar kadınların beyaz giymesi ile bağlantılı olarak ortaya çıkmıştır. Beyaz yas, Fransa'nın hüküm süren kraliçeleri için bir gelenek haline gelmiştir (Understanding the different colors of mourning, 2019). Eşlerini kaybeden kraliçelerin beyaz giyme geleneğine daha yakın zamanlı örneklerde de rastlamak mümkündür. Belçika Kralı Boudouin'in ölümü (1993) ile Kraliçe Fabiola eşinin cenazesinde beyaz giysiler tercih etmiştir (Şekil 3) (Isaacs, 2020, s. 10).

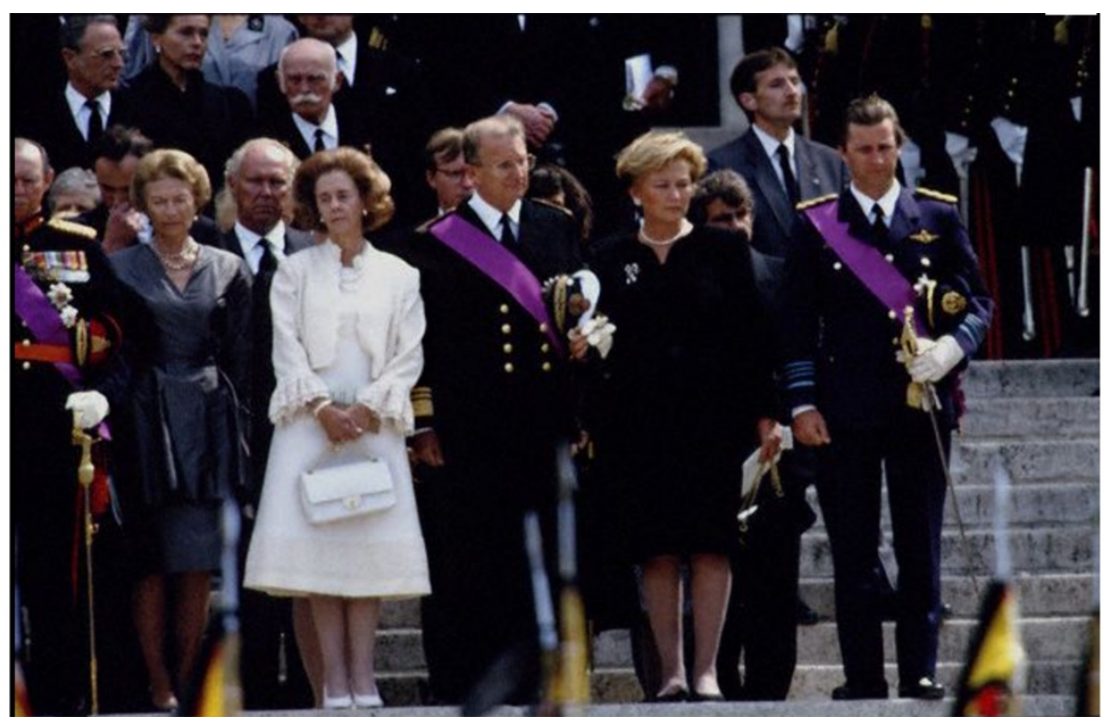

Şekil 3. Belçika Kralı Boudouin'in cenazesi ve eși Kraliçe Fabiola, (The Royal Forums, 2005).

Evlilik ritüeli de gerek kültür gerek inanç etkisi ile farklılık gösterebilmektedir. Beyaz ve saflık ilişkisinin bir örneği de evlilik ritüelinde kadınların beyaz gelinlik tercihidir. Beyaz renkli ve prenseslerin elbiselerine benzer gelinlikler, evrensel bir gelin sembolü haline gelmiştir (Gordon, 2011, s. 257-258). Antik Roma kültüründe beyaz her zaman saflığın sembolü olmuştur. Fakat gelinliklerde beyaz moda olana kadar beyazın sembolik anlamı ve genç kıza kazandırdığı masum ve saf imajı batı kültürlerinde birincil öneme sahip olmamıștır. 18. yüzyılda Avrupa 'da siyah ve altın favori olmak üzere mavi, pembe ve açık kahverengi gelinlikler tercih edilmiștir. Amerika'da beyaz gelinlik geleneği 19. yüzyılda bașlamıștır. Bu dönemin modalarında brokar ve ağır ipekli kumaşlar yerini, gece elbiseleri ve gelinliklerde muslin, organze, ince tül ya da keten gibi daha ince kumaşlara bırakmıştır. Moda olan bu kumaşlar ise çoğunlukla beyaz renkli olmuştur. 19. yüzyılın başlarında beyaz gelinlikler moda haline gelmiş, zengin ailelerin finanse edebildiği bir ürün olarak statü göstergesine de dönüşmüştür (Friese, 1997, s. 52).

Ritüeller aynı zamanda iletişimsel hareketler de gösterebilmektedir. Çoğu ritüel kendi içerisinde iletişimsel faaliyetleri barındırsa da bazıları amaçları ve yöntemleri doğrultusunda daha belirleyici olabilmektedir. Yoruba kültüründen bir örnekte beyaz iplik ve dokuma faaliyetinin bir ritüel içerisinde yer aldığı görülmektedir. Yorubalılar için beyaz iplik mecazi anlamı ile cennetten gelmektedir. Beyaz iplikler 
iyi ruhları çeken, iyileştirme özelliği olan ve kötü ruhları uzak tutan bir üründür. Yorubalıların atalarının ruhları ve insanlar arasında aracılık edebilmek amacı ile beyaz kumaşlar dokudukları bilinmektedir. Bir diğer ritüel örneğinde ise beyaz iplikler Endonezya'nın Sumbawa adasında yașayan Wawo halkının kutsama ritüellerine de aracılık etmektedir. Adada bir ev inşa edilmeden önce Wawo halkı, inşaat için oluşturulan deliklerin içerisine beyaz ipliklerin bulunduğu bir tencere su dökülmesiyle yapının sağlık ve saflık ile kutsandığına inanmaktadır (Gordon, 2011, s. 257).

Günlük yaşantının bir parçası olan mendil gibi tekstil ürünleri de iletișimsel roller üstlenebilmektedir. Mendiller, dünyada birçok kültürde yer edinmiş, işlevsel kullanımları ve beraberinde tasarımları ya da renkleri bir çeşit sözsüz iletişim aracı haline gelmiştir. Avrupa'da mendiller Othello'nun Desdemona'ya aşkının sembolü olarak sunduğu mendil ile popüler hale gelmiştir. Osmanlı Dönemi'nde de beyaz mendiller 'seni seviyorum' anlamı taşıyan hediyeler olmuştur (Ekinci, 2016). Nakkaş Sinan Bey'e ait olan Fatih Sultan Mehmet portresinde sultan bir elinde kırmızı gül bir elinde beyaz mendil tuttuğu görülmektedir (Şekil 4). Sultanın (...) tuttuğu mendil göstergesi yan anlamlar olarak Fatih'in aşk ehlinden ince ruhlu bir kişi olduğuna ve bu muhabbetin iletişimine gönderme yapmaktadır (Tonguç, 2019, s. 210).
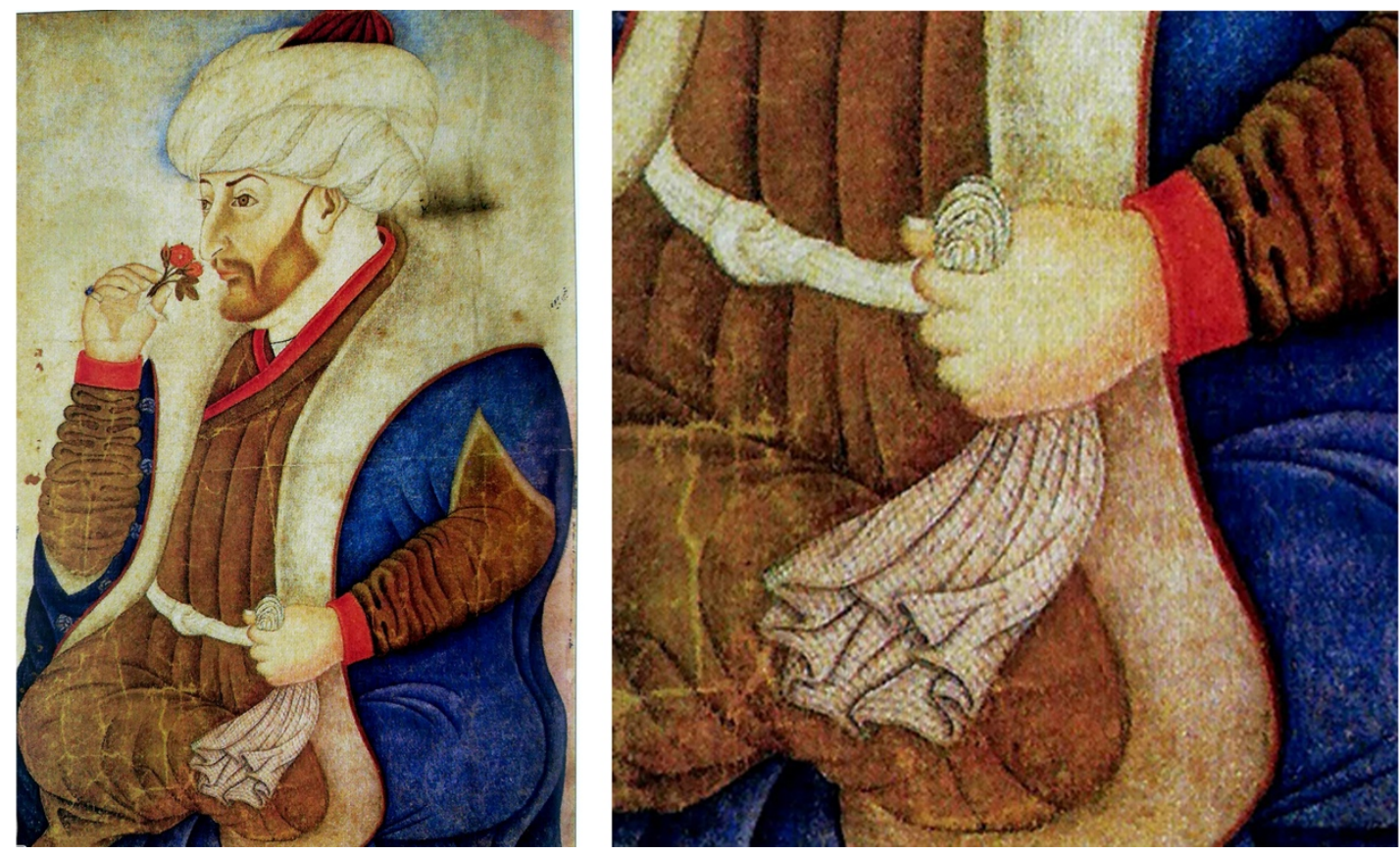

Şekil 4. Sultan II. Mehmet'in gül koklayan portesi, Nakkaş Sinan Bey, 1460 (Günaydın, 2020).

Mendiler gibi bayraklar ya da sancaklar da beyaz renk etkileşimi bağlantılı olarak sözsüz iletişim rolü üstlenebilmektedir. Beyaz bayraklar, evrensel olarak bir ateşkes sembolü ya da barışçll bir teslimiyet sinyali olarak kabul edilmektedir (Nazri vd., 2015, s. 9) Devlet ve kültür kapsamında da örnekler mevcuttur. Osmanlı'nın bilinen ilk bayrağı da beyazdır. Bu bayrak Osman Gazi'ye Anadolu Selçuklu Devleti hükümdarı tarafından bağımsızlık alameti olarak gönderilmiştir. Genel olarak Devlet-i Aliyye bayraklarında beyaz kullanımının Hz. Peygamber'in ak sancağından geldiği düşünülmektedir (Soysal, 2010, s. 220-229). Hz. Muhammed'in beyaz bir sancağı “Hz. Muhammed Mekke’ye girdiğinde, sancağı beyazdı" (Sunnah, t.y. b) hadisinde de geçmektedir. Ak sancaklar da Osmanlı'da kullanılmış, Yavuz Sultan Selim dönemine kadar tek sancak olarak yer edinmiştir (Tez, 2009, s. 307-308).

\section{3. İdeoloji ve Statü}

Bir fikir, bir düşünce ya da bir inanç insanları bir araya getiren ve belirli faaliyetler yapmaya yönlendiren bir güç olarak nitelendirilebilmektedir. Bu doğrultuda belirli bir ideoloji çevresinde gelişen faaliyetlerde giysiler ya da tekstiller sembolik anlamlar üstlenen, görsel bir imaj yaratan ve kişi ya da fikir hakkında bilgi veren araçlara dönüşebilmektedir. Renklerin anlamı ve sembolizmi de bu doğrultuda ürünleri şekillendirebilmektedir.

Fransa'da Antik Yunan'ın zirve dönemi elbiselerine benzer yükseliş elbiselerinin kullanımı, Neoklasizm'e verilen bir karşılık olarak nitelendirilmektedir. 18. yüzyılın sonlarında sanatçllar devrim desteklerini bu elbiseler aracılığı ile görselleştirilebilmiştir. Bu duruma 1788'de ressam Élisabeth Vigée Le Brun verdiği 
'Yunan' kostümü akșam yemeği örnek gösterilebilmektedir. Élisabeth'in davetine katılım gösteren kadınlar dönemin rokoko renkleri yerine beyaz elbiseler ile katılım göstermiștir. Yunan estetiğine sahip bu beyaz elbiseler yakın bir zamanda siyasi bir sembol haline de gelmiştir. 7 Eylül 1789'da seçkin 11 sanatçının eşleri ve dönemin entelektüelleri mücevherlerini National Assembly'e bağışlarken beyaz elbiseler giymiş ve bu elbiseleri sosyal adaletin bir sembolü haline getirmişlerdir. Bu elbiselerin yalın tasarımı kişisel bir kısıtlama içinde olunduğunu ve azınlığın çoğunluk için hayırseverliğini ifade ettiği düşünülmüştür. Dönemin kültür ve sanat çalışmalarında kadın portreleri beyaz elbiseler ile donanmıştır (Şekil 5a ve 5b). Louis-Sébastien Mercier'in 1798'ler gözleminde, pazar günleri Atina keten elbiselerinin neredeyse her kadın tarafından giyildiğinden bahsetmektedir. Yüksek belli, ince muslinden yapılmış yalın beyaz elbiseler aynı zamanda, modanın Fransız Devrimi'ne bir çeșit övgüsü olarak kabul edilmektedir ve liberté, égalité, fraternité ${ }^{1}$ talebine terzilik becerisi ile verilen bir yanıt olmuştur. Bu elbiseler, kadınları korselerden ve can acıtan şekillendiricilerden uzaklaştırarak fiziksel anlamda da özgürlük sağlamıştır. Elbiseler değişmeyen kesimi ve rengi ile eşitlikçi bir imaj yaratmış; rokoko tarzının aksine mütevazı görünmüş ve kardeşlik algısı yaratmıştır. 1793’te resmi olarak kıyafet kısıtlamalarından kurtulan ve özgürce giyinme hakkı kazanan Fransızlar giyimlerinin yarattığı imajdan sıyırmış ve daha özgür bir biçimde tartışabilme ve fikirlerini beyan edebilme fırsatı kazanmışlardır. "Beyaz elbise, bugün kısmen inşa edebileceğimiz karmaşık ve çok yönlü bir anlambilimle 'konuşan giysinin' paradigmatik bir örneğidir" (Lubrich, 2016, s. 2-20).

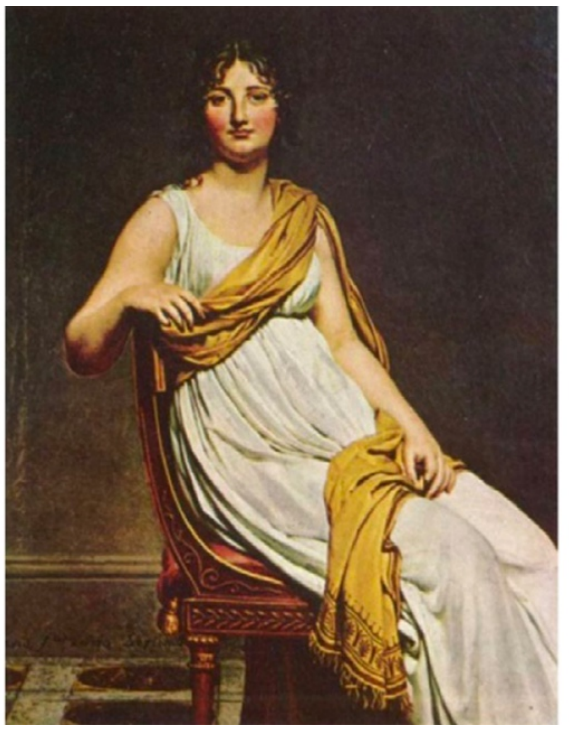

(a)

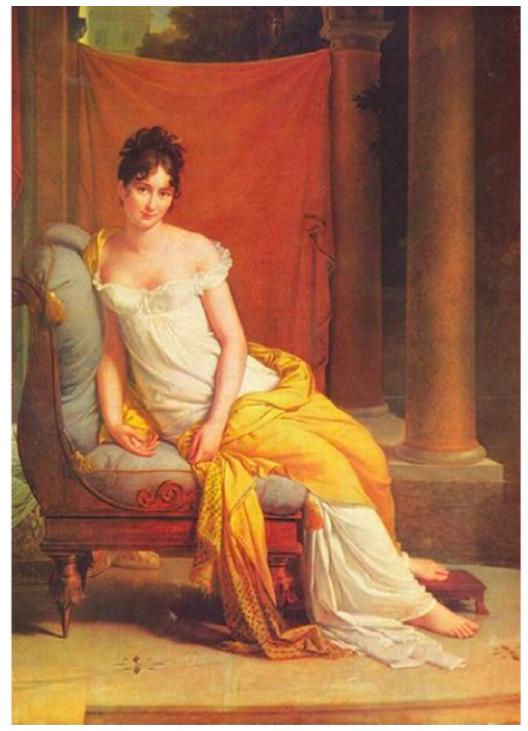

(b)

Şekil 5a. Madame de Verninac, Jacques-Louis David, 1799, Louvre (Lubrich, 2016, s .5). 5b. Juliette de Récamier, François Gérard, 1805, Musée Carnavalet, Paris (Lubrich, 2016, s. 5).

Tarihte beyaz aksesuarlar, bazı toplumlarda adalet ve yargı gücü ile ilişkilendirilmiştir. Bu doğrultuda bir örnek olarak beyaz göğüslükler ve zaman içerisinde sadeleşerek dönüştüğü beyaz yaka bantları bu aksesuarlara birer örnek teşkil etmektedir. Genel olarak gögüslükler, fonksiyonel bir amaçtan çok görsel ve sembolik bir amaca hitap eden ve mahkeme giysilerinde yer alan bir aksesuar olmuştur. Gögüslükler, 1640 'larda tercih edilmeye başlanmış ve 1860'larda günümüzde de rastlanabilen ve en sade hali olan iki dikdörtgen şekline ulaşmıştır (Haley, 2017). Hindistan'da beyaz yaka bantları sadece avukatlar tarafından kullanılabilen ve onların sembolü haline gelen bir aksesuardır (Şekil 6). Beyaz yaka bantlarının kökenleri esasen İngiltere'ye dayanmaktadır. Eski İngiliz Mahkemelerinde beyaz yaka bantları avukatların üniformalarının bir parçası olmuştur. Bu iki parça beyaz kumaşın avukat yakalarında bir araya gelmesi Tablets of the Laws' ya da Tablets of Stone'u temsil ettiği düșünülmektedir. Bu yaka bantları aynı zamanda savunma ve yargı mesleğinin amblemi olarak da kabul edilmektedir (Why do lawyers need to wear white band instead of a tie?, 2017).

\footnotetext{
1 "Liberté, égalité, fraternité; "Özgürlük, Eşitlik, Kardeşlik"' anlamına gelen Fransızca motto, 1789 Fransız İhtilali'nin simgelerindendir. Eski Fransız Frank'ının arkasında yazılı olan olan bu söz, bugün Fransız Avrosu'nda da yazılıdır.” (Türkçebilgi, 2020).

${ }^{2}$ Hz. Musanın eski Eski Ahitte bahsedilen tabletleri (Haley, 2017)
} 


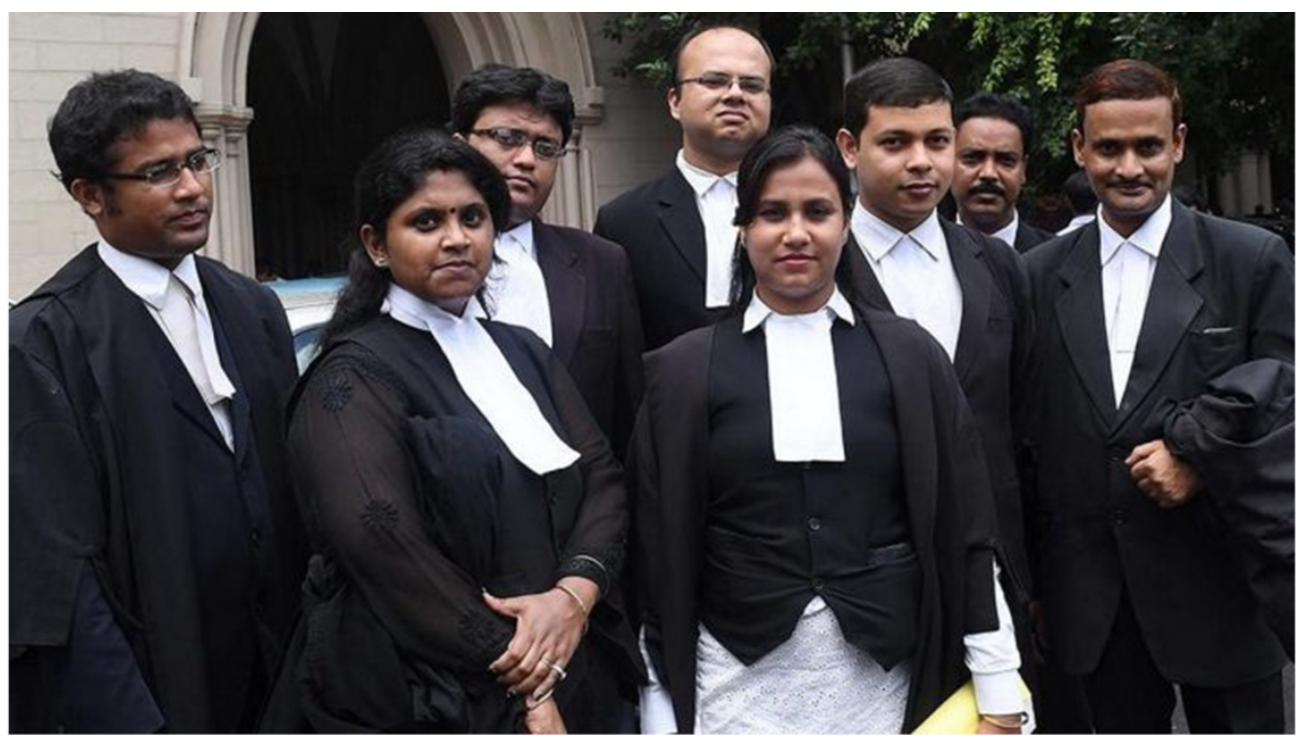

Şekil 6. Beyaz yaka bantları ile Hindistanlı avukatlar (The Print, 2020).

Giysilerin ve renk etkileşimlerinin statü ile ilişkili örneklerine rastlamak mümkündür. Beyaz; dini, kültürel ve psikolojik anlamları ile sosyal boyutta statü çağrıșımlarına aracıllk edebilmektedir ve bu doğrultuda bir kişinin görevi, sorumlulukları ve rütbesi gibi bağlantılarla ilişkilendirilebilmektedir. Bu durum Türk tarihinde açıkça gözlenebilmektedir. Eski Türk devletlerinde, devletin hükümdarlarının ve üst düzey yöneticilerinin hakim rengi beyaz olmuștur. Toplumsal düzeyde kullanımında ise Eski Türkler beyaz, köle ve cariyeler ise kara çadırlarda yaşamışlardır (Özcan, 2008, s. 279)

Benzer bir biçimde Osmanlı'da beyaz daha çok devleti yöneten kişileri temsil eden bir renk olmuştur. Osmanlı padişahları çoğunlukla beyaz kumaştan yapılmış burma sarık tercih etmiştir. Kanuni Sultan Süleyman Dönemi'nde beyaz sarıkların Türkler tarafından kullanılması, kırmızı ve siyah renklerin ise Müslüman olmayanlar için kullanılması uygun görülmüștür (Tez, 2009, s. 311-312). Ulema mensupları da örfi tarzda beyaz sarıklar kullanabilmiştir (Dinçer Berdibek, 2017, s. 77). Beyaz giysiler Osmanlı törenlerinde de yer almıștır. Bu duruma bir örnek olarak Ertürk kitabında bahsettiği II. Beyazıt'ın tahta çıkış töreni örnek gösterilebilmektedir. Ölen padişahın yas dönemi bittikten sonra yerini alan sultana yapılan kılıç kuşanma töreninde, matemin bittiğini göstermek amacı ile, uğurlu bir renk olarak da kabul edilen beyaz, tören kıyafetlerinde tercih edilmiștir (Ertürk, 2018, s. 64). Toplumsal düzeyde ise giysiler kişilerin inanışları ya da etnik kökenleri hakkında bilgi verdiği durumlara rastlamak mümkündür.

Statü ve sınıf göstergesi olarak gösterilebilecek bir diğer ürün ise beyaz gömleklerdir. Beyaz erkek gömlekleri; kökleri Viktorya Dönemi'ne uzanan geçmişi ile sosyal sınıf ve maddi varlı̆̆ın önemli bir sembolü olmuş, ağırbaşllı̆ı̆ın ve istikrarın güçlü bir amblemi olarak yorumlanmıştır. Sosyal ayrım ve giysilerin renkleri arasındaki bağlantı, bir çeşit refah göstergesi olarak da yorumlanabilen 'beyaz yakalı ve mavi yakalı' terimlerini de ortaya çıkartmıştır. Beyaz yakalar, zırha benzetilebilen yüksek boyutlu örnekleri ile kişilerin aşağıya doğru bakmalarını zorlaştırmış ve bir çeşit statü sembolü haline gelmiștir. Kolalanmış sert ve yüksek yakalar elit ya da seçkin olarak nitelendirilebilen kişileri, rahat çalışabilmek için daha alçak yakaları tercih eden çalışan kesimden ayırt edilir kılmıştır (The story of ... the men's White shirt, 2014).

Beyazın oldukça kolay kirlenebilen bir renk olması, sürekli temizlik işlemi gerektirmesi bu imajın oluşmasındaki nedenler olarak gösterilebilmektedir. 1850'lerden önce beyaz gömleklerin kullanımı daha çok erkek giyiminde yaygın olmuştur ve kadınların kullanımına uygun bulunmamıştır. Bu durum beyaz gömleklerin erkeklik ve iktidar ile ilişkilendirilmesine neden olmuş ve erkekleri saygın ve işinde uzman bir imaj yaratımında desteklemiştir. Beyaz gömleklerin sert ve üçgen yakası ve oturan kesimi erkeklik anatomisini resmeden başarılı bir tasarım olmuştur.

Beyaz yakın zamanlı olarak ahlak ile ilişkilendirilmiş, toplumun bir üyesi olarak kişinin dürüstlüğünün, dindarlığının ve saygınlığının bir işaretçisi olmuștur (Arsıya, 2016). 1920'lerde Coco Chanel'in de aralarında yer aldığı tasarımcılar cinsiyetler ve sınıflar arasındaki sınırları yıkan ve rahatlık sunan kadın giysi tasarımları sunmuştur. Zamanla etekler yerine pantolonlar, korseler yerine erkek gömlekleri 
görülmeye bașlanmış ve tasarımcllar beyaz gömleklerle kadın modasına katkıda bulunmuştur (Klerk, 2020).

\subsection{Hijyen}

Beyaz renkli giysiler kirlendiklerinde, kiri diğer renklere görece daha fark edilir kılmaktadır. Bu doğrultuda beyaz, kişinin ve bulunduğu ortamın bir çeşit temizlik işaretçisi olarak yorumlanabilmektedir. Hijyenin önemli olduğu mekanlarda ya da kişiyi hijyenik olmaya teşvik edilmek istenen meslek gruplarının üniformalarında da bu doğrultuda beyaz renk tercih edilebilmektedir. Hastane, mutfak, laboratuvar gibi ortamlarda çalıșanlar ve denizciler beyaz üniformaları ile özdeşleşmiş gruplardır.

Beyaz önlükler 19. yüzylla dayanan geçmişi ile genel olarak tüm doktorlar tarafından giyilen ve zihinde öncelikle temizlik ve saflık ile ilişkilendirilebilen giysilerdir. Beyaz önlükler, doktorların bilimsel pozisyonlarını temsilen laboratuvar önlükleri giymeleri ile kabul görmeye başlamıştır (Gordon, 2011, s. 258). Genel olarak doktorların ve hemşirelerin kendi giysileri üzerine giydikleri beyaz ameliyat önlükleri, hastayı ve doktoru kirlenmekten koruma amacını taşımaktadır (Blumhagen, 1979, s. 112).

Beyaz, duygusal boyutta bir soğukluk imajı yaratabilmektedir. Beyaz önlükler de bu doğrultuda hastaların doktorun kendisi ile duygusal ve kișisel düzeyde ilișki kuramayacağını düşünmesini desteklemektedir (Nazri vd., 2015, s.13). Beyaz önlüklerin aynı zamanda hastaların gözünde masum, dürüst, güvenilir ve güçlü bir imaj kazandırdığı düşünülmektedir. Beyaz önlük sembolizminde hekim olmanın anlamı, sosyal kavramı ile sentezlenmiştir (Blumhagen, 1979, s. 111-115).

Doktorlar için beyaz önlük 20. yüzyılın sonlarında bir çeşit tören aracına da dönüşmüştür. Beyaz önlük töreni, 1993 yılında Arnold P. Gold Foundation'ın iş birliği ile Columbia University College of Physicians and Surgeons'ta başlatılmıştır. Tören kapsamında ilk defa beyaz önlük giyecek olan öğrencilere, üst sınıf öğrencileri yardımcı olmaktadır (Şekil 7). Bu tören öğrencilere ettikleri Hipokrat yeminini ve beraberinde doktor olmanın sorumluluklarını hatırlatma amacı taşıyan bir çeşit doktorluğa geçiş töreni olarak tanımlanabilmektedir (The White coat - a universally recognized medical uniform, 2009).

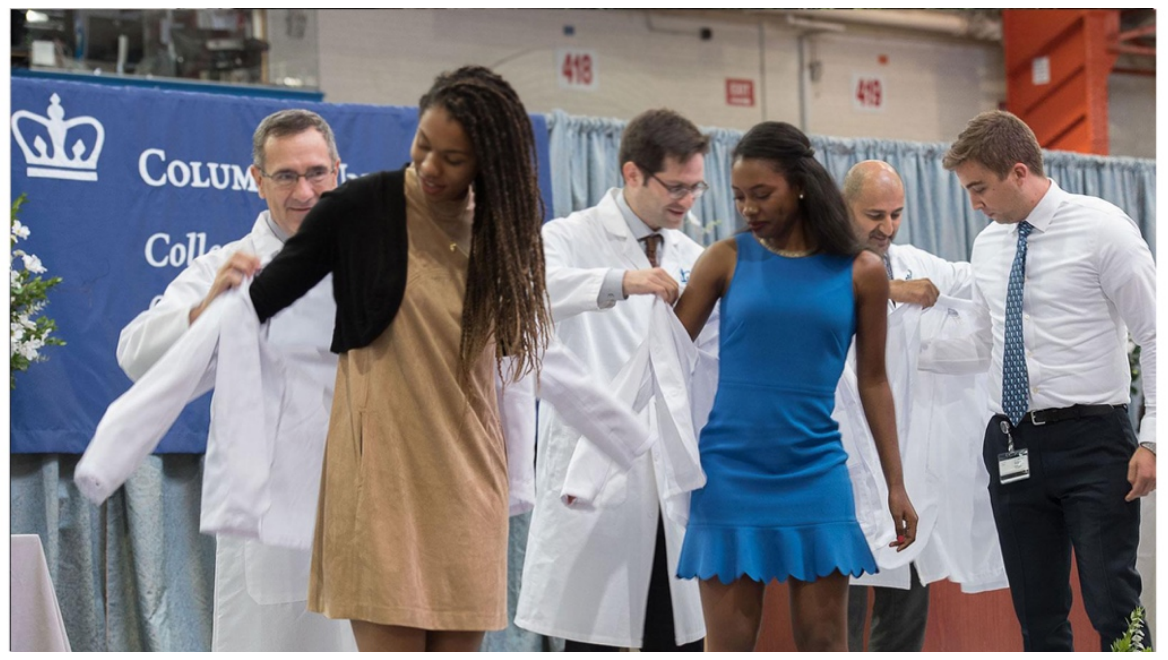

Şekil 7. Columbia University Vagelos College of Physicians and Surgeons, Beyaz Önlük Töreni (Columbia University, t.y.).

Denizcilerin üniformalarının geçmişten günümüze çoğunluklu olarak beyaz renklerde olması çeşitli nedenler ile ilişkilendirilmektedir. Beyaz pamuklu kumaşların geçmişte çoğunlukla kendi rengi ile kullanımının, bilinen en eski mesleklerden denizciliğin üniforma rengini etkilediği düşünülmektedir. Sosyal boyutta ise çeşitli çağrıșımlara sahip olmuştur. Beyazın barışı simgelemesi dünya keşifleri gerçekleştiren denizcilerin barışçıl bir mesaj iletmesine de yardımcı olmuştur. Fiziki boyutta ele alındığında ise beyaz güneş ışınlarını yansıtarak kişiyi serin tuttuğu düşünülen ve kolayca kirlenebilen bir renk olması ile tercih edilen bir renk olduğu düşünülebilmektedir. Bu doğrultuda beyaz üniformalar kirin kolayca fark edilmesini sağlayarak kişiyi temiz olmaya teşvik edebilmektedir. Arama kurtarma çalışmalarında ve karanlık deniz şartlarında ise kişiyi fark edilir kılmaktadır (Maritimetraining, t.y.).

Beyaz üniformaları tercih eden bir diğer meslek grubu ise mutfak çalışanlarıdır. Yemek yapım ve sunum aşamaları, hijyen ve beraberinde güven imajı ihtiyacını ortaya çıkartmaktadır. Beyaz, mutfakların iç dekorasyonları ve mutfak çalışanlarının giysilerinde kullanımları ile temizlik imajını desteklemektedir. 
Aşçı ve şef giysilerinde, şapkalarında, masa örtülerinde, peçeteliklerde ve garson manşetlerinde beyaz kullanımı bu imajın bir yansıması ve uygulaması olarak örnek gösterilebilmektedir. Bu ürünler, beyaz şef șapkalarına benzer biçimde mesleki bir statü (The history of the chef's hat, 2015) imajı da gösterebilmektedir.

\subsection{Protesto ve Farkındalık}

Beyazın anlamsal çağrışımlarının tekstil ve giyim ürünleri ile bir araya getirildiği bir diğer amaç protesto ve farkındalık aktiviteleridir. Bu doğrultuda beyaz renk eşitlik arayışlarında, yaşanan kötü olayların hatırlatılması ve beraberinde duyurulmasında tercih edilen bir renk olmuștur.

1900'lerin başlarında, Amerika'da ve İngiltere'de kadınlar oy hakkı elde etmek amacı ile bir hareket başlatmış ve bu doğrultuda törenler ve yürüyüşler düzenlemişlerdir. Beyaz bu organizasyonlarda saflık ve bilgelik temsili ile katılımcılar için uygun görülen üç renkten biri olmuştur. Beyaz giysiler ırk ve ekonomik durumu yansıtmaksızın bir araya getirici bir güç oluştururken, kadınlar için uygun fiyata mal edebilecekleri demokratik bir üniforma haline gelmiştir (Şekil 8) (Shaw, 2020).

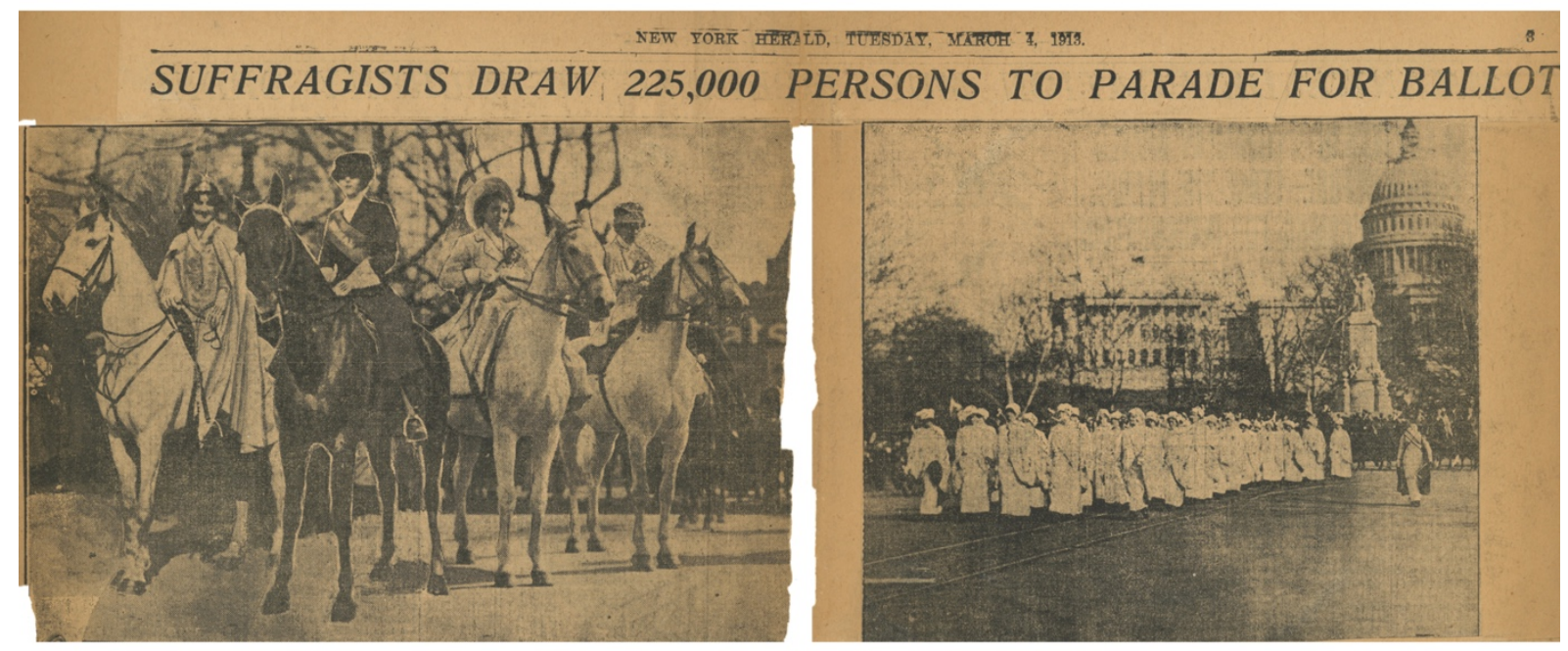

Şekil 8. 4 Mart 1913, New York Herald'dan Washington D.C.'deki kadınların oy hakkı geçit törenini bildiren makalenin bölümleri (Internet Archive, 2019).

Beyazın sahip olduğu bu duygusal ve manevi bağlar, geçmişten günümüze birçok siyasetçi kadının renk tercihlerini etkilemiştir. Geraldine Ferraro'nun 1984'te Demokrat başkan yardımcısı adaylığı kabul edildiğinde Demokratik Ulusal Kongre'de beyaz bir takım giymesi, Hillary Clinton'ın seçim kampanyasında beyazı seçmesi ve topluluk önüne çıkarken beyaz giysiler tercih etmesi ve Clinton destekçilerinin seçime beyaz giysiler giyerek gitmesi ve desteklemesi verilebilecek güncel örnekler arasındadır (Arsıya, 2016).

Beyaz rengin önceki örneklerde de belirtildiği üzere kişileri belirli bir amaç doğrultusuna getirme ve birleştirme etkisi güncel kampanyalar ile farklı amaçlar doğrultusunda devam etmektedir. Moda dünyasında birçok markayı, tasarımcıyı ve beraberinde destekçisini bir araya getiren Business of Fashion kampanyası bu duruma bir örnektir. \#TiedTogether, yani birlikte bağlandık kampanyası 2017'yılında; cinsiyet, ırk, din ayrımı yapmaksızın insanların beraberliğini ve bağlarını göstermek amacı ile beyaz bandanaların görsel bir araç olarak kullanıldığı bir girişimdir. Tiedtogether kampanyası dünyanın dört bir yanına, New York, Londra, Milano, Paris moda haftalarına ulaşmış ve beyaz bandanalar ile beraberlik ve dayanıșma mesajını dünyaya duyurmuştur (Amed, 2017).

Uniteinwhite beyaz gömlek kampanyası Witchery firmasının Ovarian Cancer Research Foundation iș birliği ile gerçekleşen bir girișimdir. Bu kampanya ile yumurtalık kanserinde erken teşhis testine farkındalık yaratılmak istenmektedir. Witchery OCRF beyaz gömlek koleksiyonlarının satışından elde edilen fon ise araştırmacı bilim insanlarına, yenilikçi projelere ve temel araştırma ekipmanlarına finansal destek sağlamaktadır (Witchery, t.y.) Kampanya görselleri ve haberleri de ayrıca kişilere sağlık testlerinin ve erken teşhisin önemini hatırlatmaktadır. Bu doğrultuda seçilen beyaz gömlekler ise gerek ideolojik rolü gerek beyaz rengin çağrışımları etkisi ile uygun bir ürün olarak seçildiği düşünülebilmektedir. 
Belirli olaylara dikkat çekilmesi, anımsatılması ya da dünya kamuoyuna duyurulması kapsamlarda çeşitli organizasyonlar, törenler ya da faaliyetler düzenlenebilmektedir. Bu doğrultuda dikkat çekilmek istenen durum çeşitli araçların ya da sembollerin desteği ile görsel olarak da desteklenebilmektedir. Bu doğrultuda beyaz tekstil ürünlerinin kullanıldığı örnekler mevcuttur.

White Armband Day, yani Türkçesi ile beyaz kolluk günü, her yıl 31 Mayıs'ta Bosna-Hersek'in kuzeyindeki Prijedor kasabasında gerçekleşen ve bir çeşit etnik katliam olayı olarak yorumlanan olayı anma günüdür. 1992'de yaşanan ve etnik temizlik olarak nitelendirilen bu olayda beyaz tekstiller Sırp olmayan kişileri işaretlemek için kullanılmıştır. Anma törenlerinde ayrımcılığın zararlarına dikkat çekmek ve ölen kişileri anmak amacı ile katılımcıların beyaz kolluk takmaları beklenmektedir (White Armband Day, 2017).

Bali'de beyaz kumaş; barış, şefkat, birlik ve uyum özlemi anlamına gelmektedir. 2002'de Kuta Plajı'nda, 184 kişinin ölümüne neden olan terör olayı sonrasında ise beyaz tekstiller anma organizasyonlarının bir parçası haline gelmiştir. Bu anma organizasyonlarında Hindu, Müslüman, Hıristiyan ve Budist inanışlarına sahip kişiler sahilde toplanarak 60 metre uzunluğunda beyaz bir kumaşı başları üzerinde gererek taşımış ve ölüler için dua etmişlerdir (Gordon, 2011, s. 257).

\section{Sonuç}

Renk ve ürün etkileşiminin bir örneği olan beyaz tekstiller ve giysiler, geçmişten günümüze beyazın kendi çağrışımları ile bağlantılı olarak çeşitli roller üstlenen ve belirli amaçlar doğrultusunda şekillendirilen ürünler olmuştur. Çalışma kapsamında yapılan araştırmada beyazın giysi ve tekstil ürünlerinde daha çok kutsallık, saflık, enerji, bekaret, güç, güven, sakinlik, temizlik çağrışımlarına aracılık ettiği örneklere rastlanılmıştır. Beyazın fonksiyonel katkıları da anlamsal çağrışımlarını destekleyici bir rol oynamıştır. Din ve inanç ile bağlantılı gelişen tekstil ve giysi örneklerinde beyazın daha çok günahsızlık, kutsallık, masumiyet, bekâret ve adanmışlık çağrışımlarını desteklediği görülmektedir. Musevilik, Hristiyanlık, Müslümanlık, Budizm gibi büyük kitlelere hitap eden dinlerin sözlü ve yazılı kaynaklarında, tasvirlerinde, geleneklerinde ve uygulamalarında beyaz giysi ve aksesuarlara yer verilmektedir. Mevcut örnekler doğrultusunda beyazın; peygamberlerin, kutsal kişilerin, din adamlarının giysilerinde ve aksesuarlarında tercih edildiği; ibadethane tekstillerinde, ayin giysilerinde, kutsal günler için önerilen giysi ve aksesuarlarda sıklıkla kullanıldığı saptanmıştır.

Beyaz, insan ile etkileşimiyle kültürel çağrışımlar kazanarak geleneksel uygulamalarda da yer almıştır. Beyaz tekstil ve giysi ürünleri; ataları ile iletişim kurma, kutsama, ölüm, yas ve evlilik gibi ritüellerinde bir araç olarak yer almış, görsel ve manevi boyutta desteklemiştir. Beyazın; bekaret, saflık, enerji, huzur ve günahsızlık çağrışımları mevcut örneklerde baskın olmuştur. Evlenirken kadınların beyaz elbiseler tercih etmesi, ölülerin beyaz renkli tekstiller ile gömülmesi, tutulan yasın beyaz giysiler ile görselleștirilmesi günümüzde de örneklerine rastlanabilen kullanımları arasındadır. Geleneksel sözsüz iletişimde ise beyaz mendiller; aşk ve sevginin bir ifadesi olmuştur. Baskın sözsüz iletişim örnekleri ile öne çıkan beyaz bayraklar daha çok inanç, güç ve barışın temsilcisi olarak yorumlanmıştır.

Beyaz tekstillerin ve giysilerin kullanımları, belirli bir ideoloji çevresinde bir araya gelen insanlar arasında birlik duygusu yaratmış, faaliyet ve uygulamalarına da aracılık etmiştir. Beyazın parlak bir renk olarak dikkat çekici olması, umut, eşitlik ve adalet çağrışımları yaratması, geçmiş örneklerinin anlamsal ve işlevsel referansları, tercih edilen bir renk olmasında etkili olduğu gözlenmektedir. Fransız Devrimi sonrasında kadınların Yunan elbiselerinden ilham alan beyaz elbiseler tercih etmesi, hükümdarlar ve yöneticilerin beyaz giysi ve aksesuarlar ile statülerini görsel olarak ifade etmesi, avukatların beyaz yakalar ile adalet ve eşitliği vurgulaması, beyaz giysilerin sosyal sınıf, varlık ve cinsiyetçi ayrım yaratması örnekler ile somutlaştırılmıştır.

Temizlik çağrışımı ile beyaz renk, mesleki üniformaları ve çeşitli aktivite giysilerini de etkilemiştir. Beyaz, doktor giysilerine; hijyen, sorumluluk, güç, duygusal nötrlük, umut gibi çağrışımlar kazandırmıştır. Hastane, laboratuvar ve mutfak görevlilerinin hijyen imajını güçlendirmiştir. Beyaz, denizci üniformalarında barıșın sembolik bir işaretçisi olmuş, yansıtıcı bir renk olması ve kiri fark edilir kılması ile işlevsel boyutta kazanımlar sağlamıştır.

Beyaz renk gerek kendi çağrışımları gerek geçmiş tekstil ve giysi örnekleri ile çeşitli protesto ve farkındalık çalışmalarında yer almış, destekleyici bir rol üstlenmiştir. Bu doğrultuda eşitlik için yapılan protestolarda, farkındalık yaratılmak istenen olaylarda ve anma törenlerinde sıkça kullanıldığı belirlenmiştir. 
Beyaz tekstil ve giysi örneklerinde etkileşim kurduğu ürünü anlamsal boyutta etkileyen ve çoğu zaman ürünün kendi anlamını ikinci plana taşıyan bir renk olmuştur. Beyaz, insan ile anlamlandırılmaktadır ve uygulamaları ile șekillenmektedir. Geçmiș kullanımları ve tekrarlayan anlam referansları ile beyazın gelecek uygulamalarında da benzer ve yeni çağrışımlar ile tercih edileceği öngörülebilmektedir.

\section{Kaynakça}

Allsaintanglican (t.y.). Altar Colors - Meanings. https://allsaintsanglican.com/altar-colors-meanings/

Amed, I. (2017, 8 Șubat). Wear a white bandana, because we are all \#tiedtogether. Businessoffashion. https://www.businessoffashion.com/articles/news-analysis/what-is-the-white-bandanatiedtogether

Arsıya, İ. (2016, 16 Kasım). Evolution of the iconic White shirt, Dailysabah, https://www.dailysabah.com/feature/2016/11/16/evolution-of-the-iconic-white-shirt

Blumhagen, D. W. (1979). Doctor's white coat, the image of the physician in modern America. Annals of Internal Medicine, (91)1, 111-116.

Britannica (t.y.). White. https://www.britannica.com/science/white-color

Castelli, E. (1986). Virginity and it's meaning for women's sexuality in Early Christianity. Journal of Feminist Studies in Religion, (2)1, 61-88.

Catholic Liturgical Colors (2018, 9 Mayıs). Matthew, https://matthewfloristandmonuments.com/catholicliturgical-colors/

Columbia University. (t.y.). Columbia University Vagelos College of Physicians and Surgeons. https://www.ps.columbia.edu/education/academic-programs/md-program/md-studentresources/office-student-affairs/white-coat

Desk, J. M. (2011, 9 Mayı). Why widows wear White? Daily Bhaskar. https://web.archive.org/web/20140814071321/https://daily.bhaskar.com/news/JM-whywidows-wear-white-2089623.html

Dinçer Berdibek, Z. (2017). 'Abbâsî İmâme' terimi üzerine bir değerlendirme. Journal of Turkish Language and Literature, (3)1, 74-83.

Edwards, B. (2004). Color: A course in mastering the art of mixing colors. Penguin Group (USA) Inc.

Ekinci, E. B. (2016, 19 Şubat,). Handkerchiefs: The secret language of love. Daily Sabah. https://www.dailysabah.com/feature/2016/02/19/handkerchiefs-the-secret-language-of-love

El-Buhârî, M. İ. İ. (2009). Sahîh-i Buhârî ve tercemesi, (M. Sofuoğlu, çev.). Ötüken Neşriyat Yayınevi.

Ertürk, N. (2018). Türklerde giyim kuşam. Hayalperest Yayınevi.

Etimolojiturkçe (t.y.). Beyaz. https://www.etimolojiturkce.com/kelime/beyaz

Friese, S. (1997) A consumer good in the ritual process: the case of the wedding dress. Journal of Ritual Studies, (11)2, 47-58.

Gordon, B. (2011). Textiles: The whole story. Thames \& Hudson, 203-233.

Gupta, R. (2011). Death beliefs and practices from an Asian Indian American Hindu perspective. Death Studies, 35(3), 244-266.

Günaydın, E. (2020, 28 Mayıs). İki karanın ve iki denizin hakanı Fatih Sultan Mehmet, Bafra55. https://www.bafra55.net/iki-karanin-ve-iki-denizin-hakani-fatih-sultan-mehmet-702yy.htm

Haley, S. (2017, 1 Kasım). \#Wednesdaywisdom: What is Jabot, and why do barristers wear them?. Lawyer Monthly. https://www.lawyer-monthly.com/2017/11/wednesdaywisdom-what-is-a-jabot-andwhy-do-barristers-wear-them/

Harvey, J. (2008). Giysiler, renk ve anlam. Sanat Dünyamız, (107), 76-86.

Internet Archive (2019). 4 Mart 1913'te New York Herald'dan Washington D.C.'deki kadınların oy hakkl geçit törenini bildiren makalenin bölümleri. https://ia601707.us.archive.org/21/items/12019.03.02-suffragists-draw/1\%3B2019.03.02_Suffragists_Draw.jpg 
Isaacs, F. (2020). Do I have to wear B-black to a funeral?: 112 etiquette guidelines for the new rules of death. The Countryman Press.

Jameson A. B. (1848). Sacred and legendary art, Longman, Brown, Green and Longmans.

Jarvis, A. (2007). The dress must be white, and perfectly plain and simple: Confirmation and First Communion Dress, 1850-2000. Costume, (41)1, 83-98.

Klerk, A. D. (2020, 27 Temmuz). The history of the hero: The White shirt. Harpersbazaar, https://www.harpersbazaar.com/uk/fashion/a32904745/history-white-shirt/

Knowing the differences between albs and surplices (2018, 1 Kasim). Churchgoers, https://www.churchgoers.com/blogs/albs/knowing-the-differences-between-albs-and-surplices

Kosloski, P. (2017, 20 Nisan). Why do priests wear White albs?. Aleteia, https://aleteia.org/2017/04/20/why-do-priests-wear-white-albs/

Kunt, S. ve Güngör, A. (2017). Aziz Yuhanna'nın vahiy kitabı çerçevesinde yedi kiliseler ve bu kiliselerin Türkiye inanç turizmindeki yeri. Gazi Üniversitesi Turizm Fakültesi Dergisi, (1), 71-92.

Lubrich, N. (2016). The little white dress: politics and polyvalence in Revolutionary France. Fashion Theory, 20(3), 273-296.

Manevi destek dayanışma (2019). İhram içerisinde Hac ibadetini gerçekleştiren Müslümanlar. https://manevidestekdayanisma.com/tavaf/

Maritimetraining. (t.y.) 10 Reasons why navy uniforms are White. http://www.maritimetraining.in/documents/10\%20Reasons\%20Why\%20Navy\%20Uniforms\% 20are\%20White.pdf

Meydan, C., ve Yıldız, G., (2018). Bir iletişim aracı olarak “tekstiller”, Atatürk Üniversitesi Sosyal Bilimler Enstitüsü Dergisi, 22(2), 905-915.

Nazri, M. K, N, Z., Khair, N. S. H., Yusoff, A, B, M., Razzak, M, M, A..Nazri, N. J. Z. ve Ishak, M. M. (2015). Colour from the perspective of hadith: an Overview, SHS Web of Conferences, 18, 04005.

Ögüt, S. (t.y.) İhram. TDV İslam Ansiklopedisi. https://islamansiklopedisi.org.tr/ihram

Özcan, B. A. (2018). Türk ve Slav kültüründe siyah renk. Akademik Tarih ve Düşünce Dergisi, 5(18), 269292.

Pomfret, J. (2006). Chinese lessons: Five classmates and the story of the New China. Henry Holt and Co.

Shaw, S. (2020, 5 Şubat). The history of women wearing suffragette White, the color presents a centuryold history fo women's rights activism. Crfashionbook. https://www.crfashionbook.com/ fashion/a26261899/the-history-of-women-wearing-suffragette-white/

Shurpin, Y. (t.y.). Why do we wear a white kittel on Yom Kippur?. Chabad, https://www.chabad.org/library/article_cdo/aid/4829/jewish/Why-Do-We-Wear-a-WhiteKittel-on-Yom-Kippur.htm

Smithsonian Libraries. (t.y.). The science of color, https://library.si.edu/exhibition/color-in-a-newlight/science

Sorularla İslamiyet (t.y.). Kefen. https://sorularlaislamiyet.com/kaynak/kefen-0

Soysal, M. E. (2010). Tarihsel süreçte bayrak ve sancaklarımız, A. Ü. Türkiyat Araştırmaları Enstitüsü Dergisi [TAED], (42), 209-239.

Stith, J. (2015). Child brides to the patriarchy: unveiling the appropriation of the missing girl child, Journal of Feminist Studies in Religion, 31(1), 83.

Sunnah. (t.y. a). Kitab Al-Jihad. https://sunnah.com/abudawud/15/116

Sunnah. (t.y. b). The Book on Hajj. https://sunnah.com/tirmidhi:877

Tez, Z. (2009). Tekstil ve giyim kuşamın kültürel tarihi. Doruk Yayımcılık.

The history of the chef's hat (2015, 24 Ağustos). Escoffier. https://www.escoffier.edu/blog/culinaryarts/the-history-of-the-chefs- 
hat/\#: :text=Symbolism\%20of \%20the\%20chef's\%20hat\&text=White\%20is\%20considered\%20 the $\% 20$ best,ways $\% 20$ to\%20 cook\%20an\%20egg.

The Print (2020). Beyaz yaka bantları ile Hindistanlı Avukatlar. https://theprint.in/judiciary/bar-councilappeals-to-pm-modi-for-allowance-to-financially-weak-lawyers-amid-lockdown/387208/

The Royal Forums. (2005). Belçika Kralı Boudouin'in Cenazesi ve Eşi Kraliçe Fabiola, https://www.theroyalforums.com/forums/f159/funeral-of-king-baudouin-i-august-7-1993-a1313.html

The story of ... the men's white shirt (2014, 14 Mayıs). The Conversation,

https://theconversation.com/the-story-of-the-mens-white-shirt-26312\#: :text= For $\% 20$ men $\% 2$ C $\% 20$ the $\% 20$ influence $\% 20$ of,part $\% 20$ hidden $\% 20$ by $\% 20$ outer\%20garments.

The White coat - a universally recognized medical uniform (2009, 10 Şubat). Endocrine Today. https://www.healio.com/news/endocrinology/20120325/the-white-coat-a-universallyrecognized-medical-uniform

Tonguç, A. (2019). Geleneğin yenilenmesi: minyatür, bakış ve farklı görme rejimleri bağlamında "Fatih portreleri" çözümlenmesi. Sosyal ve Kültürel Araştırmalar Dergisi, (5)9, 193-216.

Türkçebilgi. (t.y.) Liberté, égalité, Fraternité, https://www.turkcebilgi.com/ libert\%C3\%A9,_\%C3\%A9galit\%C3\%A9,_fraternit\%C3\%A9

Understanding the different colors of mourning (2019, 23 Aralık). Osirissoftware. https://osirissoftware.com/2019/12/23/understanding-the-different-colors-of-mourning/ \#: :text=The\%20idea\%20 of\%20white\%20mourning,bereaved\%20children\%20and\%20unmarr ied\%20women.

Wearing White for Shabbat. (2016, 16 Aralı). Jewishtreats. http://www.jewishtreats.org/2016/12/wearing-white-for-shabbat.html?m=1

White Armband Day. (2017, 31 Mayıs). Srebrenica. https://www.srebrenica.org.uk/whathappened/history/white-armband-day/

Whitfield, K. (2018, 18 Eylül). Yom Kippur 2018: What time does Yom Kippur start tonight ? Express, Home of the Daily and Sunday Express. https://www.express.co.uk/news/world/1019149/yom-kippur2018-what-time-does-yom-kippur-start-tonight

Why do lawyers need to wear white band instead of a tie? (2017, 31 Ağustos). Pathlegal, https://www.pathlegal.in/Why-do-lawyers-need-to-wear-white-band-instead-of-a-tie--blog1248389

Wikimedia (2007). Bir grup çocuğun ilk Efkarsitiya ayini portresi, Holyrood School, Swindon, 1949. https://commons.wikimedia.org/wiki/File:First_Communion_1949.jpg

Witchery (t.y). Support and research. https://www.witchery.com/features/our-calling/

Yu, H. C. (2014). A cross-cultural analysis of symbolic meanings of color, Chang Gung Journal of Humanities and Social Sciences, (7)1, 49-74. 